УДК 159.922 .27

DOI https://doi.org/10.26661/2310-4368/2021-4-11

\title{
СОЦІАЛЬНО-ПСИХОЛОГІЧНІ КРИТЕРІЇ ФОРМУВАННЯ ЛІДЕРСЬКОГО ПОТЕНЦІАЛУ В ЮНАЦЬКОМУ ВІЦІ: ЕМПІРИЧНІ ПОКАЗНИКИ
}

\author{
Ткалич М. Г. \\ доктор психологічних наук, дочент, \\ професор кафедри психології \\ Інститут підготовки кадрів державної служби зайнятості Украӥни \\ вул. Нововокзальна, 17, м. Київ, Україна \\ orcid.org/0000-0003-4101-9659 \\ mtkalych@gmail.com \\ Баранова А. М. \\ аспірантка кафедри психології \\ Інститут підготовки кадрів державної служби зайнятості Украӥни \\ вул. Нововокзальна, 17, м. Київ, Україна \\ orcid.org/0000-0002-7195-5803 \\ kishka_83@meta.ua
}

Ключові слова: лідерство, лідерські якості, лідерський потенціал, критерії лідерського потенціалу, юнацький вік, гендерні відмінності, індивідуальнопсихологічні особливості.
Стаття присвячена аналізу результатів емпіричної частини дослідження соціально-психологічних критеріїв формування лідерського потенціалу в юнацькому віці. До переліку значущих характеристик сучасної молодої людини відносять лідерський потенціал як прояв цілеспрямованої активності суб'єкта, який перетворює дійсність та самовдосконалюється. У статті критерії сформованості лідерського потенціалу було виділено відповідно до розробленої в теоретичному розділі структурної моделі лідерського потенціалу: особистісний, поведінковий та ситуаційний. Відзначено, що оптимальним періодом для формування лідерського потенціалу особистості $є$ юнацький вік, зважаючи на прагнення юнаків до самостійності, ініціативності, індивідуалізації життєвих перспектив, на схильність до налагодження суспільних контактів. Емпіричне дослідження $(\mathrm{n}=205)$ дозволило виявити гендерні відмінності й індивідуально-психологічні особливості особистості, які виступали критеріями лідерського потенціалу (здатність до ефективної комунікації, здатність до вирішення конфліктів та труднощів, здатність до організаційної діяльності, гнучкість мислення, високі інтелектуальні здібності, адекватна самооцінка). Доведено, що в юнацькому віці більшість лідерських якостей у дівчат набагато краще розвинені, аніж у хлопців. Данні діагностичного оцінювання та виявлені особливості в сукупності своїй підтверджують гіпотезу щодо впливу окремих чинників на формування лідерського потенціалу. Відзначено, що лідерський потенціал осіб юнацького віку в сучасних умовах переважно розвивається стихійно, отже, визначено потребу в розробленні програм психологічного супроводу в соціально-виховній роботі 3 юнацтвом із метою розвитку лідерського потенціалу. 


\title{
SOCIO-PSYCHOLOGICAL CRITERIA FOR THE FORMATION OF LEADERSHIP POTENTIAL IN ADOLESCENCE: EMPIRICAL INDICATORS
}

\author{
Tkalych M. H. \\ Doctor of Psychological Sciences, Associate Professor, \\ Professor at the Department of Psychology \\ Ukrainian State Employment Service Training Institute \\ Novovokzalna str., 17, Kyiv, Ukraine \\ orcid.org/0000-0003-4101-9659 \\ mtkalych@gmail.com
}

Baranova A. M.

Postgraduate Student at the Department of Psychology

Ukrainian State Employment Service Training Institute

Novovokzalna str., 17, Kyiv, Ukraine

orcid.org/0000-0002-7195-5803

kishka_83@meta.ua

Key words: leadership, leadership qualities, leadership potential, criteria of leadership potential, adolescence, gender differences, individual psychological features.

\begin{abstract}
The paper is devoted to the analysis of the empirical research results of the study of socio-psychological criteria for the formation of leadership potential in adolescence. The list of significant characteristics of a modern young person takes into account the leadership potential as a manifestation of purposeful activity of the subject, which transforms reality and self-improvement. In the paper, the criteria for the formation of leadership potential have been identified in accordance with the structural model of leadership potential developed in the theoretical section: personal, behavioral and situational. It has been noted that the most optimal period for the formation of leadership potential of the individual is adolescence, given the desire of young people for independence, initiative, individualization of life prospects, and the tendency to establish social contacts. Empirical research $(n=205)$ revealed gender differences and individual psychological characteristics of the individual, which acted as criteria for leadership potential (ability to communicate effectively, ability to resolve conflicts and difficulties, ability to organize, flexibility of thinking, high intellectual abilities, adequate self-esteem). It has been proven that in adolescence the vast majority of leadership qualities in girls are much better developed than in boys. The data of diagnostic assessment and the identified features together confirm the hypothesis of the influence of individual factors on the formation of leadership potential. It is noted that the leadership potential of adolescents in modern conditions mainly develops spontaneously, so the need to develop programs of psychological support in social and educational work with youth in order to develop leadership potential.
\end{abstract}

Постановка проблеми. В умовах соціально-економічних змін в Україні на сучасному етапі актуалізується проблема формування соціально активної, компетентної та творчої особистості. До переліку значущих характеристик сучасної молодої людини відносять лідерський потенціал як прояв цілеспрямованої активності суб'єкта, який перетворює дійсність та самовдосконалюється.

Сучасний світ потребує ініціативних людей, здатних здійснювати свідомий самостійний вибір, які мають розвинуте почуття власної гідності, здатних до особистісного самовдосконалення. Це пояснюється тим, що людина протягом життя виконує різні соціальні ролі, зокрема й керівника мікро(сім'я) або макроколективу (організація, виробництво тощо). Саме тому лідерство - це природна необхідність людини. Воно є найдавнішою формою об'єднання людей і забезпечує порядок в організації, рух уперед. Лідерська самореалізація - важливий аспект функціонування творчої особистості. 
Проблему лідерства, розвитку лідерських якостей особистості висвітлено в дослідженнях вітчизняних науковців (В. Веснін, Д. Виханський, М. Гаврилюк, Т. Гура, С. Дубовська, О. Свтихов, Н. Жеребова, Л. Карамушка, Р. Кричевський, Є. Кузьмін, В. Лозниця, А. Лутошкін, Н. Мараховська, В. Москаленко, Б. Паригін, А. Петровський, О. Пономарьова, Л. Уманський, О. Уманський, О. Чернишов, Ф. Хміль та інші), але більш досконало ця тема розвинена та розроблена зарубіжними фахівцями (К. Бланшард, Р. Блейк, Е. Богардус, М. Вебер, I. Вешлер, В. Врум, Р. Ділтс, П. Друкер, Дункан Джек У., Ф. Йєттон, Б. Карлофф, Д. Крюгер, Курт Левін, Ренсис Лайкерт, Ф. Массарик, Дуглас Макгрегор, М. Маскон, С. Сміт, А. Сосланд, Р. Танненбаум, Ф. Фідлер, Д. Френсис, П. Херсі та багато інших). Вони створили моделі та висунули теорії, які набули світового визнання, затвердили себе як правдиві та науково обгрунтовані ідеї.

Упродовж останніх двадцяти років у психологічній науці почали з'являтися роботи американських (Д. Гоулман, К. Ебромс, Р. Стернберг, Ф. Хесселблейн), французьких (М. Ке де Врі) та українських психологів (В. Бажанюк, В. Камишин, А. Мітлош, В. Моляко, В. Татенко), присвячені проблемі лідерської обдарованості та лідерського потенціалу.

Водночас проблема соціально-психологічних чинників формування лідерського потенціалу в юнацькому віці потребує більш детального розгляду й емпіричного аналізу.

Метою статті є аналіз результатів емпіричного дослідження соціально-психологічних критеріїв (здатність до ефективної комунікації, здатність до вирішення конфліктів та труднощів, здатність до організаційної діяльності, гнучкість мислення, високі інтелектуальні здібності, адекватна самооцінка) та гендерних відмінностей формування лідерського потенціалу в юнацькому віці.

Виклад основного матеріалу дослідження. Почнемо 3 теоретичного обгрунтування емпіричного етапу дослідження. Проблема лідерства вивчалася 3 погляду різних підходів, але в усіх підходах лідерство визначається як один із найважливіших компонентів ефективного керівництва, процес соціального впливу, за якого лідер шукає найбільш адекватні форми добровільної участі підлеглих із метою досягнення організаційних цілей, або процес впливу лідера на групову активність, який має бути спрямований на досягнення мети. Цей процес був би неможливий, якби особистість не мала лідерських якостей, які являють собою лідерський потенціал.

На основі теоретичного аналізу проблеми можна говорити про те, що оптимальним періодом для формування лідерського потенціалу особи- стості є юнацький вік, особливість якого полягає, 3 одного боку, у прагненні юнаків до самостійності, ініціативності, індивідуалізації життєвих перспектив, 3 іншого - у схильності до налагодження суспільних контактів $[4 ; 5 ; 10]$. Саме тому 3 погляду розвитку юнацький вік характеризується як надзвичайно важливий у становленні повноцінної, соціально активної особистості, бо в цьому віці закладаються і формуються основи лідерського потенціалу, який, у свою чергу, розкривається в подальшому дорослому житті.

У контексті аналізу проблеми було виокремлено такі особистісні якості, які, на наш погляд, $\epsilon$ складовими показниками лідерського потенціалу: рішучість, ініціативність, наполегливість, чесність і порядність у відносинах, відповідальність, емпатія, високі інтелектуальні здібності, уміння слухати співрозмовника, товариськість та готовність до співпраці, високий ступінь розвитку рефлексивності, здатність впливати на інших, комунікабельність, уміння розв'язувати конфлікти, уміння себе презентувати, готовність до самостійних дій, розвиненість упевненості в собі, організованість і уміння управляти собою, наявність мотивації успіху, здатність до організаторської роботи, стресостійкість, уміння ухвалювати відповідальні рішення. На наш погляд, ці якості $\epsilon$ надзвичайно важливими у становленні особистості як лідера, саме їх сформованість є основою лідерського потенціалу.

Якщо брати до уваги той факт, що розгляд будь-якої дослідної величини має включати в себе не тільки іiі показники, але й критерії, які визначають прояв того чи іншого показника у процесі або явищі, що розглядається, то визначення рівня сформованості лідерського потенціалу в юнацькому віці маємо пов’язати з визначенням критеріїв, показників та рівнів його розвитку. Кожен критерій має складатися із сукупності основних показників, що розкривають рівні розвитку відповідної якості. Отже, будучи компонентом критерію, показник $є$ конкретним і типовим проявом одного iз суттєвих аспектів, на підставі якого можна «визнати» наявність якості, судити про рівень іiі розвитку. Щоб показник відповідав його призначенню, він повинен за кожним критерієм розкривати сутність відповідної якості [9, с. 62-75].

У нашому дослідженні критерії сформованості лідерського потенціалу було виділено відповідно до розробленої в теоретичному розділі структурної моделі лідерського потенціалу.

Отже, спираючись на складові частини лідерського потенціалу, ми виділили та структурували такі критерії сформованості лідерського потенціалу:

Особистісний критерій. На основі цього критерію виявляється рівень сформованості загальних рис лідера, ставлення до навколишнього світу 
і людей, передбачається здатність реалізувати природні задатки лідера і мобілізувати індивідуальний потенціал особистості. Показниками цього критерію є: ступінь розвитку рішучості; ступінь розвитку ініціативності; ступінь розвитку наполегливості; чесність і порядність у відносинах; ступінь розвитку відповідальності; ступінь розвитку емпатії та здатності розуміти емоційний стан людини; ступінь розвитку інтелектуальних здібностей.

Поведінковий критерій сприяє визначенню рівня орієнтованості юнаків на взаємодію 3 іншими людьми на підставі взаєморозуміння, взаємоповаги. Показники цього критерію: здатність до вміння слухати співрозмовника; товариськість та готовність до співпраці; ступінь розвитку рефлексивності; здатність активно впливати на інших; ступінь розвиненості комунікабельності; уміння розв'язувати конфлікти; уміння себе презентувати.

Ситуаційний критерій дав змогу виявити практичні аспекти формування лідерського потенціалу юнаків у будь-якій ситуації. Критерій складається $з$ таких показників, як: ступінь готовності до самостійних дій; ступінь розвиненості впевненості в собі; організованість і уміння управляти собою; наявність мотивації успіху; здатність до організаторської роботи; стресостійкість; уміння ухвалювати відповідальні рішення, незважаючи на ситуацію.

Відповідно до теоретичного аналізу і з урахуванням усіх особливостей проблеми було проведено емпіричне вивчення: по-перше, рівня сформованості лідерського потенціалу осіб юнацького віку; по-друге, особливостей впливу соціально-психологічних чинників на формування лідерського потенціалу осіб юнацького віку. Відповідно до гіпотези дослідження, у юнацькому віці в дівчат значно вищій рівень сформованості лідерських якостей, аніж у хлопців; на формування лідерського потенціалу в юнацькому віці впливають соціально-демографічні (стать, вік, здатність до ефективної комунікації, здатність до вирішення конфліктів та труднощів, здатність до організаційної діяльності) та індивідуально-психологічні (гнучкість мислення, високі інтелектуальні здібності, адекватна самооцінка) властивості особистості.

Методика й організація дослідження. Експериментальне дослідження було проведено в місті Одесі на базі однієї приватної школи-ліцею, одного НВК, трьох загальноосвітніх шкіл, а також двох профільних ліцеїв: економічного та гуманітарного (n=205). Вік досліджуваних - від 16 до 19 років.

Для визначення рівня сформованості лідерського потенціалу були використані: тест-опитувальник «Здатність до лідерства» (Р. Нємов); мето- дика Роттера «Локус-контролю»; методика ITO Собчик; методика Дембо-Рубінштейна (адаптивний варіант); методика «Велика п'ятірка» (BFQ).

Також відповідно до завдань емпіричного дослідження, метою якого було вивчення рівня обізнаності осіб юнацького віку про особливості феноменів «лідерство», «лідерські якості», «лідерський потенціал», як зазначалося, були проведені бесіди за такими темами: «Як я розумію, що таке «лідерство»?»; «Яким я бачу лідера?»; «Якими якостями має володіти лідер?»; «Як я розумію поняття «лідерський потенціал»?», а також спостереження за поведінкою осіб юнацького віку. Бесіди мали за мету виявлення ставлення юнаків до прояву лідерства, а також обізнаності про особливості феноменів «лідерство», «лідерські якості», «лідерський потенціал». Для обробки отриманих даних використовувався метод описової статистики, а також метод контент-аналізу [7].

Результати емпіричного дослідження. Контент-аналіз відповідей на запитання «Як я розумію, що таке «лідерство»?»; «Яким я бачу лідера? Хто такий справжній лідер?»; «Якими якостями має володіти лідер?»; «Як я розумію поняття «лідерський потенціал»?» із проведених бесід показав таке.

Щодо змісту поняття «лідерство», $55 \%$ респондентів уважають, що «лідерство» - риса, яка допомагає особистості бути першою. $30 \%$ респондентів уважають «лідерство» становищем у суспільстві, можливістю зайняти вищі ланки життя. Останні $15 \%$ респондентів уважають «лідерство» владою та впливом на конкретну групу людей. Далі наведемо приклади найбільш вдалих відповідей, отриманих нами під час проведення бесід:

- «коли людина впевнена у власних силах, має твердий характер і може вести за собою інших, бути прикладом для них»;

- «сукупність рис та якостей особистості, які допомагають їй бути лідером»;

- «уміння організувати і повести за собою людей, переконати їх у правильності власної думки»;

- «становище людини в суспільстві, що виявляє бачення загальних проблем, планування, ухвалення відповідальних рішень»;

- «направляти, допомагати та розвивати свій колектив у потрібному напрямі, водночас ураховувати потреби та побажання кожного»;

- «перевага однієї або кількох особистостей над іншими членами групи, що проявляється у процесі керівництва ними»;

- «коли людина може виділити себе 3 кола інших людей завдяки яскраво вираженим особистісним якостям»; 
- «лідер має ефективно організовувати команду, для якої він є прикладом».

Виходячи із цього, можемо сказати, що знання й уявлення юнаків про лідерство формуються здебільшого на основі вибіркового включення в лідерську діяльність (допомога класному керівникові або іншим учителям, співпраця зі старостою класу, наявність обов'язків старости) або спостереження за іншими лідерами, а також під впливом соціальних умов. I цим зумовлено те, що образ лідера в уяві осіб юнацького віку здебільшого має характер стереотипу.

Так, коли ми запропонували описати, яким юнаки бачать лідера та його атрибути, то $67 \%$ респондентів зобразили лідера як особу в костюмі, 3 галстуком та дипломатом, тобто юнаки часто ототожнюють лідерство та керівництво, а також формальне та неформальне лідерство. Лише $18 \%$ сприймають лідера в інноваційному, неформальному образі. Незважаючи на формальність зовнішнього образу лідера, понад третину респондентів (70\%) «справжнім лідером» уважають людину, яка вміє добре взаємодіяти з оточенням, брати на себе відповідальність та проходити складні життєві випробування. «Справжнім лідером» є людина, яка досягла своєї мети. Інші відповіді на це питання розподілилися так: $15 \%$ «справжнім лідером» бачать людину, яка бере на себе відповідальність за виконання якихось планів, проєктів, програм. Лідер, на їхню думку, завжди пропонує нові ідеї, він зробить усе заради перемоги. Наступні 10\% респондентів «справжнім лідером» уважають людину, яка може вести за собою, може вдумливо керувати. Прикладом такого лідера більшість із цієї частини респондентів обрали У. Черчілля. Останні $5 \%$ «справжнім лідером» назвали людину, яка вміє командувати та все встигає.

Серед лідерських якостей більшість респондентів (понад 75 \%) назвали такі 5 якостей справжнього лідера, як: уміння командної взаємодії, толерантність, креативність, інтелект, вплив на інших, активність. Останні більш ніж $15 \%$ наголосили на тому, що «справжньому лідерові» притаманні: комунікабельність, мотивація на досягнення успіху, харизматичність та вміння маніпулювати. $5 \%$ респондентів назвали лише активність. Отже, більшість респондентів усе ж таки мають уявлення про те, яким має бути «справжній лідер», якими якостями він має володіти.

На питання «Як я розумію поняття «лідерський потенціал»?» більшість респондентів (понад 79\%) відповіли, що це спроможність людини бути лідером. Інша частина (майже $20 \%$ ) сказали про те, що «лідерські якості» і «лідерський потенціал» це те саме.

Отже, ми бачимо, що сучасні юнаки в більшості своїй мають конкретні уявлення про те, що таке «лідерство», яким має бути «справжній лідер», якими якостями він має володіти.

Завданнями другої частини емпіричного дослідження було вивчення загального рівня сформованості здатності до лідерства. Тож, отримані результати дозволили виявити загальний рівень та результати рівнів окремих складових частин лідерського потенціалу у відсотках від загальної кількості респондентів, що представлені в таблиці 1.

Таблиця 1

Загальний рівень та результати рівнів окремих складових частин лідерського потенціалу (у \% від загальної кількості респондентів)

\begin{tabular}{|c|c|c|c|c|}
\hline \multirow{2}{*}{ Критерії } & \multirow{2}{*}{ Показники } & \multicolumn{3}{|c|}{ 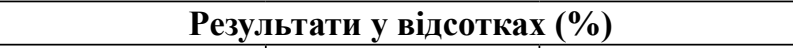 } \\
\hline & & Високий рівень & Середній рівень & Низький рівень \\
\hline 1 & 2 & 3 & 4 & 5 \\
\hline \multirow{7}{*}{$\begin{array}{l}\text { Особистісний } \\
\text { критерій }\end{array}$} & Рішучість & 43,3 & 51,2 & 5,7 \\
\hline & Ініціативність & 47,4 & 48,4 & 4,4 \\
\hline & Наполегливість & 44,5 & 45,9 & 9,7 \\
\hline & Чесність і порядність у відносинах & 38,8 & 55,8 & 5,5 \\
\hline & Відповідальність & 40,8 & 52,3 & 7,05 \\
\hline & $\begin{array}{c}\text { Емпатія та здатність розуміти емоційний } \\
\text { стан людини }\end{array}$ & 33,5 & 56,8 & 9,3 \\
\hline & Інтелектуальніздібності & 44,01 & 48,5 & 7,4 \\
\hline \multirow{7}{*}{$\begin{array}{c}\text { Поведінковий } \\
\text { критерій }\end{array}$} & Уміння слухати співрозмовника & 31,6 & 59,3 & 9,2 \\
\hline & $\begin{array}{c}\text { Товариськість } \\
\text { та готовність до співпраці }\end{array}$ & 51,04 & 41,8 & 7,2 \\
\hline & Ступінь розвитку рефлексивності & 34,9 & 55,3 & 9,8 \\
\hline & Здатність активно впливати на інших & 34,3 & 60,4 & 5,3 \\
\hline & Комунікабельність & 49,02 & 41,9 & 9,08 \\
\hline & Уміння розв’язувати конфлікти & 32,3 & 54,6 & 13,1 \\
\hline & Уміння себе презентувати & 37,03 & 55,2 & 7,7 \\
\hline
\end{tabular}


Продовження таблиці 1

\begin{tabular}{|c|c|c|c|c|}
\hline $\mathbf{1}$ & $\mathbf{2}$ & $\mathbf{3}$ & $\mathbf{4}$ & $\mathbf{5}$ \\
\hline \multirow{4}{*}{$\begin{array}{c}\text { Ситуаційний } \\
\text { критерій }\end{array}$} & Готовність до самостійних дій & 50,7 & 42,08 & 7,2 \\
\cline { 2 - 5 } & Розвиненість упевненості в собі & 40,08 & 51,4 & 8,5 \\
\cline { 2 - 5 } & $\begin{array}{c}\text { Організованість та уміння управляти } \\
\text { собою }\end{array}$ & 35,6 & 52,5 & 12,01 \\
\cline { 2 - 5 } & Наявність мотивації успіху & 55,4 & 37,2 & 7,4 \\
\cline { 2 - 5 } & 3датність до організаторської роботи & 36,5 & 55,4 & 8,1 \\
\cline { 2 - 5 } & $\begin{array}{c}\text { Уміння ухвалювати відповідальні рішен- } \\
\text { ня, незважаючи на ситуацію }\end{array}$ & 40,3 & 50,9 & 8,8 \\
\hline
\end{tabular}

Отже, розвиненість більшості зі складових частин лідерського потенціалу простежується більшою мірою на середньому рівні. Але є деякі складники, як-от комунікабельність $(49,02 \%)$, наявність мотивації успіху $(55,4 \%)$, готовність до самостійних дій $(50,7 \%)$, товариськість та готовність до співпраці (51,04\%), які розвинені на досить високому рівні. На зовсім низькому рівні $(4,4 \%) \in$ показник ініціативності. Виходячи із цього, можемо сказати, що в юнацькому віці особистість більш схильна йти на контакт, отже, більш комунікабельна і готова до співпраці. Окрім того, юнаки більш мотивовані на успіх і націлені на самостійні дії, бажаючи довести, що вони можуть все зробити без сторонньої допомоги. Усе це свідчить про те, що юнацький вік є сприятливим для формування лідера.

Відповідно до емпіричної гіпотези дослідження, розглянемо сформованість окремих складових частин лідерського потенціалу та загальної здатності до лідерства залежно від статі, яку представлено в таблиці 2.

Отримані результати засвідчили, що загальний рівень сформованості здатності до лідерства більший у дівчат (52\%), аніж у хлопців (49\%). Це може вказувати на те, що в юнацькому віці хлопці більш невпевнені в собі і не завжди можуть чітко вистроїти життєві пріоритети. Окрім цього, на відміну від юнаків, дівчата більш здатні до емпатії (дівчата $-44,6 \%$, юнаки $-32,5 \%$ ), мають більшу стресостійкість (дівчата-45,04\%, юнаки - 38,5\%). $\mathrm{y}$ дівчат набагато більше впевненості в собі (дівчата $-46,05 \%$, юнаки - 40,4\%) і мотивації успіху (дівчата $-41,9 \%$, юнаки $-31,8 \%$ ). Дівчата набагато більш самостійні, аніж юнаки (дівчата $35,4 \%$, юнаки - 29,5\%) і набагато краще вміють рефлексувати (дівчата - 45,7\%, юнаки - 43,7\%), краще вміють слухати (дівчата - 43,2\%, юнаки - 39,8\%), мають вищій інтелектуальний рівень (дівчата $-43,4 \%$, юнаки $-41,8 \%$ ). Дівчата краще вміють презентувати себе (дівчата - 38,9\%, юнаки $-36,5 \%)$. Але водночас юнаки більш ініціативні (юнаки - 36,9\%, дівчата - 35,6\%) і мають більше рішучості, на відміну від дівчат (юнаки $35,8 \%$, дівчата - 33,2\%). Юнаки швидше можуть

Сформованість окремих складових частин лідерського потенціалу : статеві відмінності (у \% від загальної кількості респондентів)

\begin{tabular}{|c|c|c|}
\hline Показники & Дівчата & Хлопці \\
\hline Рішучість & 33,2 & 35,8 \\
\hline Ініціативність & 35,6 & 36,9 \\
\hline Наполегливість & 31,4 & 32,2 \\
\hline Чесність & 34,7 & 35,6 \\
\hline Відповідальність & 33,6 & 34,5 \\
\hline Емпатія & 44,6 & 32,5 \\
\hline Інтелект & 43,4 & 41,8 \\
\hline Уміння слухати & 43,2 & 39,8 \\
\hline Товариськість & 42,2 & 34,07 \\
\hline Рефлексія & 45,3 & 43,7 \\
\hline Вплив на інших & 38,98 & 38,97 \\
\hline Комунікабельність & 34,6 & 26,6 \\
\hline Уміння розв'язувати & 39,6 & 40,4 \\
\hline конфлікти & 38,9 & 36,5 \\
\hline Уміння себе презентувати & 35,4 & 29,5 \\
\hline Самостійність & 46,05 & 40,4 \\
\hline Упевненість у собі & 38,8 & 39,2 \\
\hline Організованість & 41,9 & 31,8 \\
\hline Мотивація успіху & 31,4 & 32,2 \\
\hline Організаторські здібності & 45,04 & 38,5 \\
\hline Стресостійкість & 32,04 & 33,1 \\
\hline Уміння ухвалювати рішення & 52 & 49 \\
\hline Здатність до лідерства & & \\
\hline
\end{tabular}

себе організувати (юнаки-39,2 \%, дівчата-38,8 \%), мають більш розвинені організаторські здібності (юнаки - 32,2\%, дівчата - 31,4\%), на більш високому рівні в них розвинуто вміння ухвалювати рішення (юнаки - 33,1\%, дівчата $-32,04 \%$ ). Юнаки набагато краще за дівчат урегульовують конфлікти (юнаки - 40,4\%, дівчата - 39,6\%).

Третім етапом експериментального дослідження було виявлення кореляційних зв'язків за критерієм Пірсона, що представлено в таблиці 3. 
Таблиця 3 стресостійкість (коефіцієнт кореляції Пірсона

Матриця кореляцій показників окремих складових частин лідерського потенціалу: статеві відмінності

\begin{tabular}{|c|c|c|}
\hline Показники & Юнаки & Дівчата \\
\hline Рішучість & $-0,095$ & 0,176 \\
\hline Ініціативність & $-0,043$ & 0,544 \\
\hline Наполегливість & $-0,033$ & 0,643 \\
\hline Чесність & $-0,032$ & 0,228 \\
\hline Відповідальність & $-0,030$ & 0,673 \\
\hline Емпатія & $0,378^{* *}$ & 0,000 \\
\hline Інтелект & 0,055 & 0,435 \\
\hline Уміння слухати & 0,122 & 0,081 \\
\hline Товариськість & $0,251^{* *}$ & 0,000 \\
\hline Рефлексія & 0,059 & 0,404 \\
\hline Вплив на інших & 0,000 & 0,998 \\
\hline Комунікабельність & $0,319^{* *}$ & $-0,095$ \\
\hline Уміння розв'язувати & $-0,025$ & 0,724 \\
\hline конфлікти & & \\
\hline Уміння себе презентувати & $-0,092$ & 0,192 \\
\hline Самостійність & $0,196^{* *}$ & 0,005 \\
\hline Упевненість у собі & $0,170^{*}$ & 0,015 \\
\hline Організованість & 0,014 & 0,845 \\
\hline Мотивація успіху & $0,287^{* *}$ & 0,000 \\
\hline Організаторські здібності & $-0,029$ & 0,677 \\
\hline Стресостійкість & $0,201^{* *}$ & 0,004 \\
\hline Уміння ухвалювати рішення & $-0,029$ & 0,678 \\
\hline Здатність до лідерства & $-0,156^{*}$ & 0,026 \\
\hline ** - кореляція значуща на рівні 0,01 (двостороння); \\
* - кореляція значуща на рівні 0,05 (двостороння). \\
\hline
\end{tabular}

3 даних, представлених у таблиці 3, бачимо, що отримано такі значущі кореляції показників окремих складових частин лідерського потенціалу, як-от: емпатія (коефіцієнт кореляції Пірсона $\mathrm{r}=0,378, \mathrm{p}=0,000$ ), товариськість (коефіцієнт кореляції Пірсона $\mathrm{r}=0,251, \mathrm{p}=0,000)$, комунікабельність (коефіцієнт кореляції Пірсона $\mathrm{r}=0,319$, $\mathrm{p}=-0,095$ ), самостійність (коефіцієнт кореляції Пірсона $\mathrm{r}=0,196, \mathrm{p}=0,005)$, мотивація успіху (коефіцієнт кореляції Пірсона $\mathrm{r}=0,287, \mathrm{p}=0,000$ ), $\mathrm{r}=0,201, \mathrm{p}=0,004)$, залежно від статі. У результаті проведеного аналізу можемо зазначити, що рівень емпатії, товариськості, комунікабельності, самостійності, мотивації успіху, стресостійкості в юнаків дещо менший, аніж у дівчат. Це явище може бути спричинено декількома факторами: по-перше, на відміну від юнаків, дівчата мають більш прискорений розвиток, по-друге, під час проведення діагностики респонденти могли дати некоректні відповіді, ми не виключаємо той факт, що на відвертість респондентів міг впливати їхній особистісний стан.

Висновки та перспективи подальших досліджень. На основі теоретичного аналізу проблеми визначено, що оптимальним періодом для формування лідерського потенціалу особистості є юнацький вік, особливість якого полягає, з одного боку, у прагненні юнаків до самостійності, ініціативності, індивідуалізації життєвих перспектив, з іншого - у схильності до налагодження суспільних контактів У статті виокремлені критерії сформованості лідерського потенціалу відповідно до розробленої в теоретичному розділі дисертаційного дослідження структурної моделі лідерського потенціалу, до яких віднесено особистісний, поведінковий та ситуаційний. Проведене дослідження дозволило виявити гендерні відмінності й індивідуально-психологічні характеристики особистості, які виступають критеріями формування лідерського потенціалу (здатність до ефективної комунікації, здатність до вирішення конфліктів та труднощів, здатність до організаційної діяльності; гнучкість мислення, високі інтелектуальні здібності, адекватна самооцінка). У юнацькому віці більшість лідерських якостей у дівчат набагато краще розвинені, аніж у хлопців. Данні діагностичного оцінювання та виявлені особливості в сукупності своїй підтверджують гіпотезу щодо впливу окремих чинників на формування лідерського потенціалу; якщо брати до уваги те, що лідерський потенціал осіб юнацького віку в сучасних умовах переважно розвивається стихійно, то нами визначена потреба в розробленні програм психологічного супроводу у процесі соціально-виховної роботи з юнацтвом із метою розвитку лідерського потенціалу, у чому і вбачається перспектива подальших досліджень.

\section{ЛІТЕРАТУРА}

1. Абрамова Г. Возрастная психология. Москва : Наука, 1997. 354 с.

2. Базарова К. Лидерские качества руководителя как социально-психологический феномен. Современный кадровый менеджмент. Москва : ИПК госслужбы, 2007. Вып. 6. С. 25-41.

3. Головешко Б. Про деякі проблеми розвитку лідерських якостей у студентів вищих навчальних закладів. Проблеми та перспективи формування національної гуманітарно-технічної 
еліти : збірник наукових праць / ред. Л. Товажнянський, О. Романовський. Харків : НТУ «ХПІ», 2012. № № 32-33 (36-37). С. 89-96.

4. Грищенко I. Теоретико-методологічні засади лідерства. Наукові розвідки з державного та муніципального управління збірник наукових пращьь. 2015. Вип. 1. С. 110-122.

5. Ильин В. Психология лидерства. Москва : Юрайт, 2015. 311 с.

6. Кричевский Р. Психология лидерства. Москва : Статут, 2007. 542 с.

7. Сидоренко Е. Методы математической обработки в психологи. Санкт-Петербург : Речь, 2007. 350 с.

8. Ткалич М. Психологія гендерної взаємодії персоналу організацій : монографія. Київ ; Запоріжжя : ЗНУ, 2015. $315 \mathrm{c}$.

9. Щуркова Н. Диагностика воспитанности: педагогические методики. Воспитание: новый взгляд с позиции культуры. Москва : Пед. поиск, 1997. С. 62-75.

10. Ясвин В. Развитие лидерского потенциала старшеклассников и студентов в условиях молодежной образовательной площадки. Современная соииальная психология: теоретические подходы и прикладные исследования. 2011. № 3. С. 73-84.

11. Bartol K. Women and men in task groups. The social psychology of female-male relations. New York : Acad. Press, 1986. P. 259-310.

12. Chemers M. Leadership Research and Theory: A Functional Integration. Group Dynamics: Theory, Research and Practice. 2000. Vol. 4 (1). March. P. 27-43.

13. Eagly A. Sex differences in social behavior: A socialrole interpretation. Hillsdale, N. J. : Erlbaum, 1987. $305 \mathrm{p}$.

\section{REFERENCES}

1. Abramova G.S. (1997) Vozrastnaia psykholohyia [Age psychology]. M. : Nauka. 354 s. [in Russian]

2. Bazarova K.T. (2007) Liderskiye kachestva rukovoditelya kak sotsial'no-psikhologicheskiy fenomen [Leadership qualities of the head as a social and psychological phenomenon]. Modern personnel management, vol. 6, № 1(2), S. 25-41. [in Russian]

3. Goloveshko B.R. (2012) Pro deyaki problemy rozvytku liders'kykh yakostey u studentiv vyshchykh navchal'nykh zakladiv [Problems of student leadership skils evolution in higher academic institutions]: Coll. Science. etc. Problems and prospects of formation of the national humanitarian and technical elite, № 32-33 (36-37). - S. 89-96. [in Ukrainian]

4. Gryshchenko I.M. (2015). Theoretical and Methodological Principles of Leadership. Scientific Intelligence from the State and Municipal Management collection of scientific works. - Issue 1. S. 110-122. [in Ukrainian]

5. Il'in V.A. (2015). Psikhologiya liderstva [Psychology of leadership]. M.: Yurayt. 311 s. [in Russian].

6. Krichevskiy R.L. (2007). Psikhologiya liderstva [Psychology of Leadership]. M. : Statute. 542 s. [in Russian]

7. Sidorenko Ye.V. (2007) Metody matematicheskoy obrabotki v psikhologii [Methods of mathematical processing in psychology]. SPb. : Rech. 350 s. [in Russian]

8. Tkalych M.H. (2015). Psyhologija gendernoi' vzajemodii' personalu organizacij [Psychology of gender interaction of personnel in organizations] : [monografija]. - Kyi’v - Zaporizhzhja : ZNU, $315 \mathrm{~s}$. [in Ukrainian]

9. Shchurkova N.Ye. (1997) Diagnostika vospitannosti: pedagogicheskiye metodiki [Diagnostics of good breeding: pedagogical methods]. Education: a new view from the standpoint of culture. - M. : Ped. search, S. 62-75. [in Russian]

10. Yasvin V.A. (2011) Razvitiye liderskogo potentsiala starsheklassnikov i studentov v usloviyakh molodezhnoy obrazovatel'noy ploshchadki [Development of the leadership potential of high school students and students in the context of a youth educational platform. Contemporary social psychology: theoretical approaches and applied research]. Sovremennaya sotsial'naya psikhologiya: teoreticheskiye podkhody i prikladnyye issledovaniya. -№ 3. S. 73-84 [in Russian].

11. Bartol K.M. (1986). Women and men in task groups. The social psychology of female - male relations. N.Y. : Acad. Press, P. 259-310.

12. Chemers M.M. (2000). Leadership Research and Theory: A Functional Integration. Group Dynamics: Theory, Research and Practice. 2000. Vol. 4 (1) March. P. 27-43.

13. Eagly A.H. (1987). Sex differences in social behavior: A social role interpretation. Hillsdale, N. J. : Erlbaum, 305 p. 